\title{
The concept of green infrastructure and urban landscape planning: a challenge for urban forestry planning in Belgrade, Serbia
}

\author{
Nevena Vasiljević( ${ }^{(1)}$, \\ Boris Radić ${ }^{(1)}$, \\ Suzana Gavrilović (1), \\ Biljana Šljukić (2), \\ Milan Medarević (2), \\ Ratko Ristić ${ }^{(3)}$
}

\begin{abstract}
The beginning of the $21^{\text {st }}$ century has witnessed a growth in our understanding of the importance of planning urban landscapes in the context of urban population growth and unpredictable climatic conditions. In the search for responses to the challenges set by the development of contemporary urban landscapes, researchers have offered solutions based on the concept of sustainable and resilient cities, whose spatial development would be based on an interdisciplinary approach to strategy development: biodiversity, urban ecological networks and connectivity, multifunctionality and modularity. Although the concepts of a green infrastructure, in their spatial and functional dimensions, allow the application of such strategies, there are still problems when it comes to implementation and measuring the results achieved. At the same time, there is a growing discussion of the important role played by urban forestry in the context of the collaborative planning of urban landscapes and the application of the ideas of a green infrastructure. The key question is: what are the modalities of application of the concept of green infrastructure in the process of planning the development of the modern city and how can the resulting benefits be evaluated? With the modalities of application of the concept of green infrastructure in mind, we discuss its multi-scale and multifunctional dimensions as applied in the case of Serbia. The realisation of the green infrastructure concept is presented through the example of the Urban Forest Management Plan for the City of Belgrade - Mladenovac Municipality. The results of using the spatial-ecological approach in creating the plan and establishing connectivity as a new aim in forest management planning show that the implementation of the green infrastructure concept, and the achieved multifunctional ecosystem values, can be presented on the basis of the parameters of landscape metrics. In light of the new urban world, future research should focus on the application of the landscape ecological approach of the green infrastructure concept in collaborative planning at the urban landscape scale, which allows the creation of ecosystem services and benefits to human wellbeing.
\end{abstract}

Keywords: Green Infrastructure (GI), Urban Landscape Planning, Urban Forestry, Ecosystem Services, Biodiversity, Recreation, Connectivity

\section{Introduction}

The $21^{\text {st }}$ century is the century of the new urban world. Today, more than $80 \%$ of the European population lives in cities, which has led to a spatial expansion of cities that is four times greater than the expansion of the population (Poelmans \& Van Rompaey 2009, Prokop et al. 2011, Tobias 2013). These processes are changing the urban landscape pattern, as can be seen in the homogenisation of the landscape structure (a dramatic expansion of built-up areas and
(1) University of Belgrade, Faculty of Forestry, Department of Landscape Architecture and Horticulture, Belgrade (Serbia); (2) University of Belgrade, Faculty of Forestry, Department of Forestry, Belgrade (Serbia); (3) University of Belgrade, Faculty of Forestry, Department of Ecological Engineering in Soil and Water Resources Protection, Belgrade (Serbia)

@ Boris Radić (boris.radic@sfb.bg.ac.rs)

Received: Nov 13, 2017 - Accepted: May 16, 2018

Citation: Vasiljević N, Radić B, Gavrilović S, Šljukić B, Medarević M, Ristić R (2018). The concept of green infrastructure and urban landscape planning: a challenge for urban forestry planning in Belgrade, Serbia. iForest 11: 491-498. - doi: 10.3832/ifor2683-011 [online 201807-18]

Communicated by: Raffaele Lafortezza sealed soil - Zonneveld 1995, Rudnick et al. 2012) and the functional disintegration of urban landscapes (Antrop \& Van Eetvelde 2000). These changes are leading to a loss of landscape connectivity and a consequent decline in the level of landscape stability. Taking into account the impact of climate change on the urban landscape, all these factors mean that the quality of urban life has become quite unpredictable.

There has be a recent surge of interest in approaching urban landscapes "in the sense of being new and different from what was known before", where "novel urban ecosystems have 'no analog' and are increasingly the subject of research to understand their origins, ecological trajectories and opportunities for developing new management goals and approaches" (Ahern 2016). Ahern (2013) suggested some strategies for interdisciplinary discourse on urban sustainability and resilience in urban landscape planning. These include: biodiversity, urban ecological networks and con- 
nectivity, multifunctionality, redundancy and modularity and adaptive design. Much research adopts a response to the challenges of modern urban development by utilising the concept of green infrastructure (GI), which is ontologically based on Ahern's strategies for urban landscape planning (Ahern 2013, Mell 2009, Lafortezza et al. 2013a, Hansen \& Pauleit 2014).

The concept of green infrastructure is defined as a strategically planned network of natural and semi-natural elements (abbreviated hereafter to NSN) with other environmental features designed and managed to deliver a wide range of ecosystem services (EC 2013). This concept integrates two important dimensions. First, a green infrastructure has the multi-scale spatial dimension of a coherent ecological network based on the physical (spatial) and functional connectivity between different types of green areas at various spatial levels (local, regional, national, international - Ahern 2011), with various elements going to make up its physical structure (Benedict \& McMahon 2006). Second, a green infrastructure has multifunctional dimensions that are realised through a variety of ecosystem services, which are classified in the MA (Millennium Ecosystem Assessment 2005) as provisioning, regulating, cultural and supporting services. Supporting services maintain other ecosystem services where biodiversity, through natural habitats and the services of their plant and animal communities, has a central role (Tobias 2013).

As a result of all the predicted benefits, the European Union's recent climate adaptation strategy (EC 2013) promotes the adoption of green infrastructure and ecosystem-based approaches. In particular, Lafortezza et al. (2013a) presented a comprehensive analysis of green infrastructure initiatives across Europe, which resulted in the proposal of a new "Green Infrastructure Framework" as a unifying human-centred approach to multi-scale (spatial and temporal) planning for ecosystem and well-being services. It consists of "ecological hubs, links and multi-functionality in land-use management" but adds "drivers" for GI planning: ecosystem services, human well-being, social cohesion, biodiversity and sustainable development (Lafortezza et al. 2013a). According to Hansen \& Pauleit (2014) the multifunctionality of a green infrastructure network needs to take connectivity into account, because connectivity represents the spatial distribution and relationships of $\mathrm{Gl}$ elements and, consequently, the distribution of the benefits they provide. Among examples of the realisation of the green infrastructure concept on different scales in Europe, urban landscapes appear to be an especially useful level at which to develop, implement and deliver a green infrastructure.

Despite a variety of purposes that go beyond the concept of green infrastructure, we lack the tools and approaches to mea- sure the impact of the actual implementation and delivery, i.e., the social and environmental benefits (Nassauer \& Opdam 2008, De Groot et al. 2010, Hauck et al. 2013, Lafortezza et al. 2013a). At the same time, the lack of quantitative data is often mentioned in scientific literature as a problem when applying ecosystem services and a green infrastructure in practice (Albert et al. 2014a).

Ahern (2011, 2013) describes the concept of planning a landscape as a green infrastructure where landscape ecology has a central role in providing tools to understand, model and manage the frequency, magnitude and extent of urban ecosystem dynamics. The main principles of the landscape ecology approach that are relevant to the implementation of a green infrastructure in urban landscape planning are: (a) a landscape-scale approach with an explicit recognition of the relationships between pattern and process and an emphasis on structural and functional connectivity (Botequilha Leitao \& Ahern 2002, Ndubisi 2002);

(b) a multifunctional approach which aims to combine and link different ecosystem services with a connectivity dependent function (i.e., in relation to human health (recreation) and secure intact ecological systems and biodiversity) and, in that way, use the limited urban space more effectively (Ahern 2011, 2013, Lafortezza et al. 2013a).

In light of the new urban world, Randrup et al. (2005) have stressed that forestry is becoming more urban and urban forestry is at least as much about urbanity as it is about forestry. Urban forests serve as areas for recreation and entertainment and also spaces of high attention in the maintenance of biodiversity. According to the new urban world, new urban forestry should be seen as "only one of a series of strategic, interdisciplinary and participatory approaches aimed at optimising the planning and management of urban green structure in order to multiply the benefits to urban society" (Randrup et al. 2005). This has led to the emergence of new, integrated concepts and approaches. In this regard, as a result of exploring approaches and forest issues, Lafortezza et al. (2013b) reached the conclusion that forest planning and management have to be made within the landscape context with the integration of landscape ecology principles.

As result of the ratification of the European Landscape Convention, the Spatial Plan of The Republic of Serbia recognises a green infrastructure as one of the ways of applying the landscape-ecological principle of connectivity within spatial planning at the national level (Vasiljević et al. 2016). At the regional level, the Draft Plan for the General Regulation of Green Spaces of the City of Belgrade (2014) developed a green infrastructure and its elements through the core, inner and outer ring of the green spaces system. There is an obvious problem of legal adoption and implementation at the local level of planning and managing due to the lack of instruments for its delivery.

Recognising the importance of the green infrastructure concept for the urban landscape future, as well as the problems of its implementation and the lack of tools for measuring its values, in this paper we aim to find modalities of application of the $\mathrm{Gl}$ concept in the process of planning the development of the modern city and to find how the resulting benefits can be evaluated. Using the examples of the Urban Forest Management Plan for the City of Belgrade - Mladenovac Municipality (Medarević et al. 2013), this is achieved through addressing the following objectives: (1) analysing the connectivity as a multifunctional value unifying biodiversity and recreation as ecosystem services that are represented by NSN elements relevant to the urban landscape pattern; (2) proposing measures (landscape metric parameters) for connectivity as outcomes of a green infrastructure; (3) providing directions for future research by proposing a landscape ecology approach and structural and functional connectivity between green infrastructure elements (which provide different ecosystem services) as one of the new goals in the practice of urban forestry planning.

\section{Material and methods}

\section{Study area}

The investigation area is defined by the administrative boundaries of the Municipality of Mladenovac ( $44^{\circ} 26^{\prime} 56.68^{\prime \prime} \mathrm{N}, 20^{\circ}$ $\left.41^{\prime} 50.16^{\prime \prime} \mathrm{E}\right)$ located in the central part of Serbia (Fig. 1). The Municipality of Mladenovac, a suburban part of the administrative area of the Belgrade metropolitan area, covers $338.64 \mathrm{~km}^{2}$. The municipality has a population of more than 53,000 inhabitants, of whom more than half live in rural parts of the municipality.

The landscape of the municipality is defined as a broad valley with undulating relief consisting of smaller spatial units between alluvial plains of varying width. In morphological terms, it can be characterised as a combination of flatlands and hilly relief with altitudes ranging from 113 to 518 $\mathrm{m}$ a.s.l. The climate is of the mild continental type, with an annual average temperature of $10.7{ }^{\circ} \mathrm{C}$ and average annual precipitation of $649 \mathrm{~mm}$.

Urbanisation has the form of unplanned settlements characteristic of the urban fringe, whose creation and development were determined mainly by natural conditions, transport infrastructure and the vicinity of Belgrade. More significant settlement expansion and urbanisation have been recorded in recent decades.

The expansion of settlements and the destruction of autochthonous vegetation in the municipality constitute key factors of structural modification in the use of space, resulting in a drastic reduction of the area under forest from over $50 \%$ to the current 
level of about $12.5 \%$. Land use indicates the importance of agricultural activity (agricultural land use accounts for about $68.8 \%$ of the total municipal area), which is the reason why most of the natural forests have been destroyed. On the whole, forests mostly constitute remnant landscape elements of Hungarian and Turkish oak forest (Quercetum frainetto-cerris) that have survived the expansion of urban and agricultural land-use during the last and current centuries. This part of Serbia is a segment of the largest ecoregion in Europe, temperate broadleaf and mixed forests which are simultaneously, on a European level, areas subject to intensive urbanisation. At the global level this ecoregion is the most frequently analysed in the context of biodiversity loss and conservation (Correa Ayram et al. 2016).

Considering the global trends of urbanisation and land use changes on the urban fringe, the Assembly of the City of Belgrade adopted the Belgrade Afforestation Strategy in 2011 on the basis of the Law on Environmental Protection. The implementation of this Strategy through the Urban Forest Management Plan (Medarević et al. 2013), has resulted in the afforestation of 416.86 ha of land owned by the municipality. The specific topography of the sites and the ceno-ecological zonality of the landscape were the main guides for the selection of tree species which belong to the units of natural potential vegetation of broader areas: forests of Hungarian Oak and Turkish Oak (Quercetum-fraineto cerris), forests of Common Oak and Tall Greenweed (Quercetum roboris, Genisto elatae) and forests of Sessile Oak and Hornbeam (Quercio-Carpinetum).

Theoretical background of connectivity as a multifunctional value

The first step towards the establishment of a theoretical methodological basis was to analyse the functional and spatial (structural) dimensions of the concept of green infrastructure, with the aim of establishing the landscape metric parameters suitable for measuring connectivity as the main multifunctional outcome of a green infrastructure.

The spatial dimension of the concept of green infrastructure is shown through the presence and extent of NSN elements and the degree of the physical connection between them. The physical connectivity of the NSN landscape elements can be taken as the basic indicator of the degree of realisation of gene movement through species and population migrations, which are a dominant force in defining biodiversity at various spatial and organisational levels (Noss 1990, Sax \& Gaines 2003). The multifunctional dimension of a green infrastructure is shown through ecosystem services, the function of which depends on the degree of connectivity (Fig. 2). Although connectivity is usually understood as ecological connectivity, in urban areas it is also

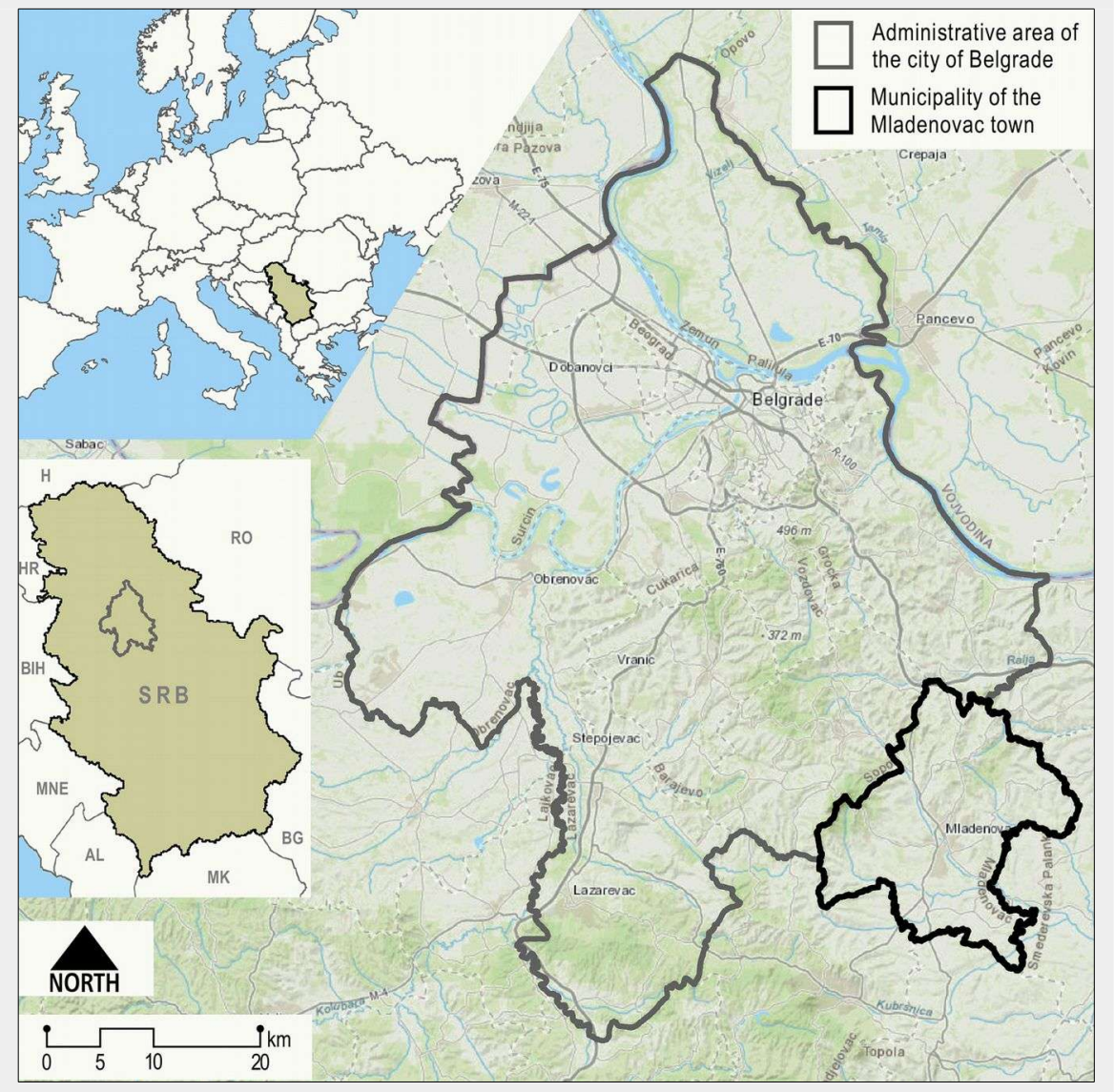

Fig. 1 - Location of the Municipality of Mladenovac in the European, Serbian and Belgrade metropolitan context.

seen as an important aspect of recreation as a social well-being or cultural ecosystem service (Pauleit et al. 2011, Daniel et al. 2012).

The size of landscape elements is one of alone can provide essential information about the characteristics of a landscape at different organisational levels (McGarigal \& Marks 1995). Landscape metric parameters the fundamental metric parameters that scape elements, which indicate the inten-

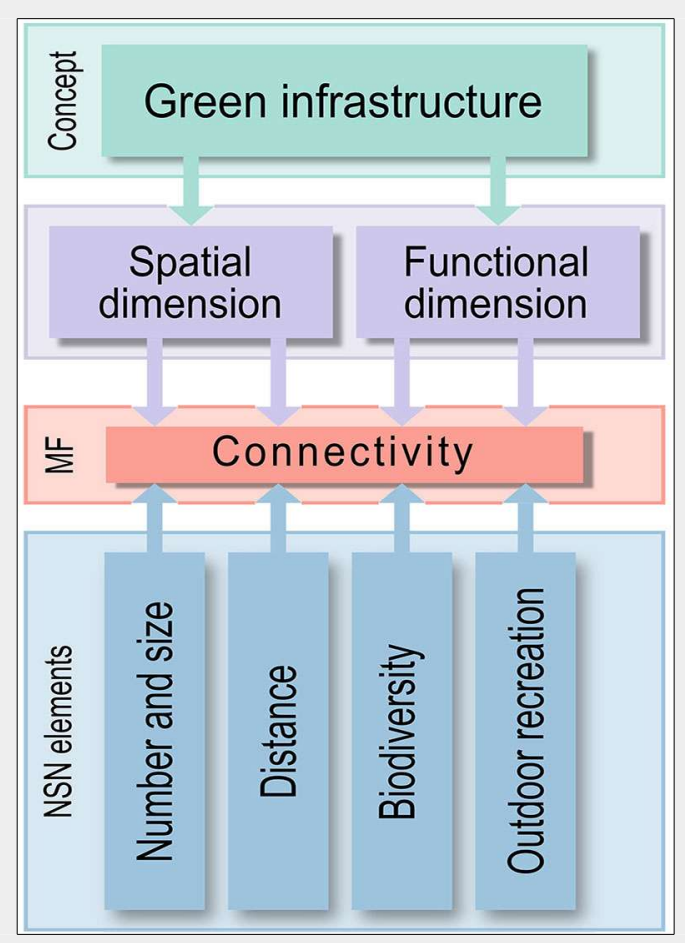

Fig. 2 - Conceptual framework for measuring connectivity as a multifunctional value. Lines between main boxes indicate relationships between the concept of $\mathrm{Gl}$, its dimension and indicators for measuring connectivity as a multifunctional value of ecosystem services and $\mathrm{Gl}$. 
sity of fragmentation, define the value of biodiversity at the landscape level (Fahrig 2003). The size metric of landscape elements strongly correlates with "species richness and the occurrence and abundance of some species" (McGarigal \& Marks 1995) and can be interpreted as a spatial indicator of the biodiversity level (Billeter et al. 2008, Kumar et al. 2006). However, this metric has several limitations, among which is that it cannot illustrate spatial properties and the distribution of elements across the analysed landscape (Botequilha Leitao et al. 2006). Furthermore, working with a metric class which refers only to the size or number of NSN elements yields weaker results than using an integral metric of the structural relationship inside a landscape matrix that is hostile to natural processes (human dominated matrix types - Prugh et al. 2008). We can, therefore, conclude that the thrust of our analysis is focused on the zones in which the influence of NSN elements is reduced or absent.

Among the various services that have a pronounced spatial aspect and for which there are also concise instruments for assessment, cultural services are poorly integrated into the measurable landscape value framework and often characterised as "intangible" and "subjective" (Casado-Arzuaga et al. 2014). In the complex process of perception of the landscape, both by locals or visitors, it has been concluded that areas with a significant number of interconnected elements that are carriers of naturalness are recognised as desirable, and are thus valued more highly (Daniel 2001, Lee et al. 2008). Although some studies identify recreation as a threat to the vitality of the ecosystem, properly planned and managed recreation can help provide a better understanding of ecological values in the area where recreation can become one of the instruments of conservation of valuable habitats (Dolnicar et al. 2008). Regarding outdoor recreation, we used some of the conclusions reached in previous studies, primarily Chan et al. (2006) and Weyland \& Laterra (2014). According to these authors, the possibility of accomplishing outdoor recreation is conditioned by the degree of naturalness of the landscapes and the presence of NSN elements in the landscape structure. According to studies that analysed perceptions of the possibility of using forests or natural areas for recreation, for optimal usage such areas should be within walking distance and optimally within $1 \mathrm{~km}$ (Hornsten \& Fredman 2000).

\section{Measuring connectivity}

In this study, connectivity was measured within the structure of the landscape at two time intervals. For the interpretation of the spatial structural elements we used the patch-corridor-matrix model (Forman 1995). The first time interval was an interpretation of the structure of the landscape with a spatial resolution of $20 \mathrm{~m}$ (minimum mapping unit is $20 \times 20$ metres) on the basis of an orthorectified aerial image from 2011. Forest elements occupy an area of $46.50 \mathrm{~km}^{2}(13.73 \%)$, urban areas $36.42 \mathrm{~km}^{2}$ (10.75\%) and the spatial matrix is agricultural land with $255.73 \mathrm{~km}^{2}(75.52 \%)$. It is important to mention that only forests can be treated as NSN homogenous landscape elements, while urban and agricultural areas have a heterogeneous structure. At the second time interval we see the landscape structure based on the Urban Forest Management Plan, which is the result of the implementation of the concept of a green infrastructure.

The landscape structure represents a domain for the formation of spatial identifiers of forest landscape elements in the form of point features with a given resolution of $20 \mathrm{~m}$ (Fig. 3a). This resolution allows the formation of a representative base appropriate for detecting small "bits of nature", which are one of the "top priority ecological indispensables" (Forman 1995) with great significance for the connectivity of NSN elements in human developed areas (Ahern 2013).
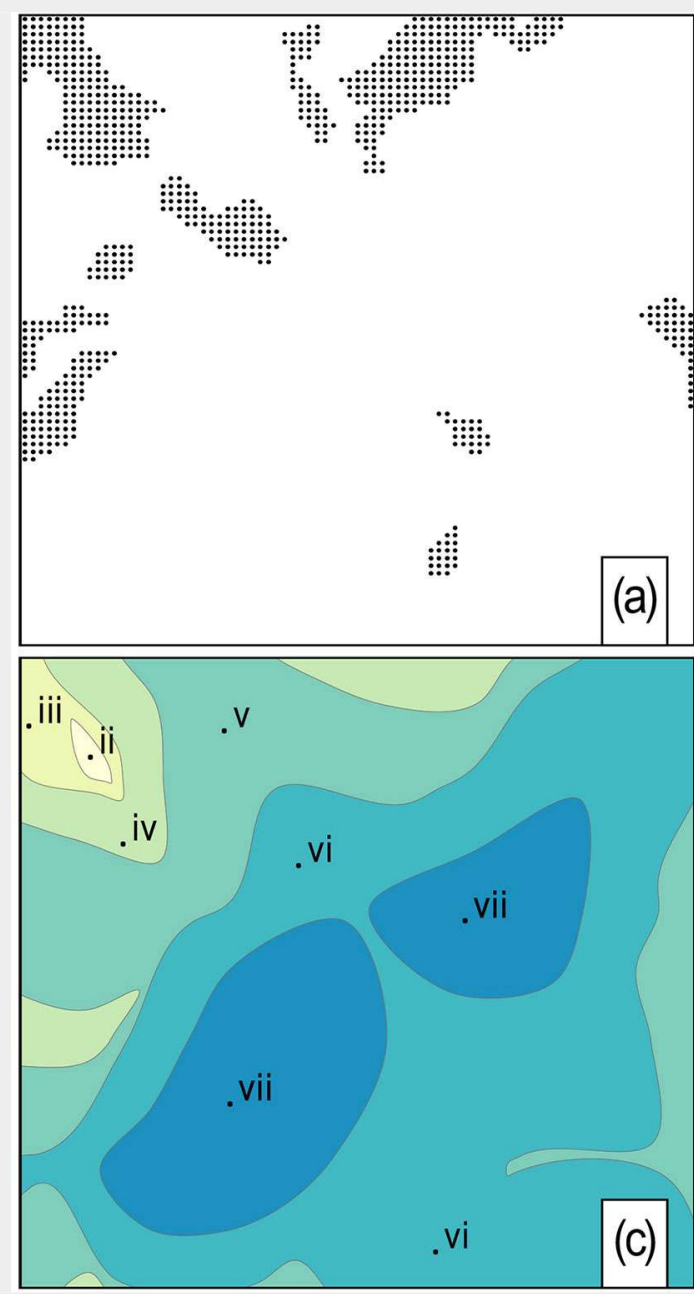
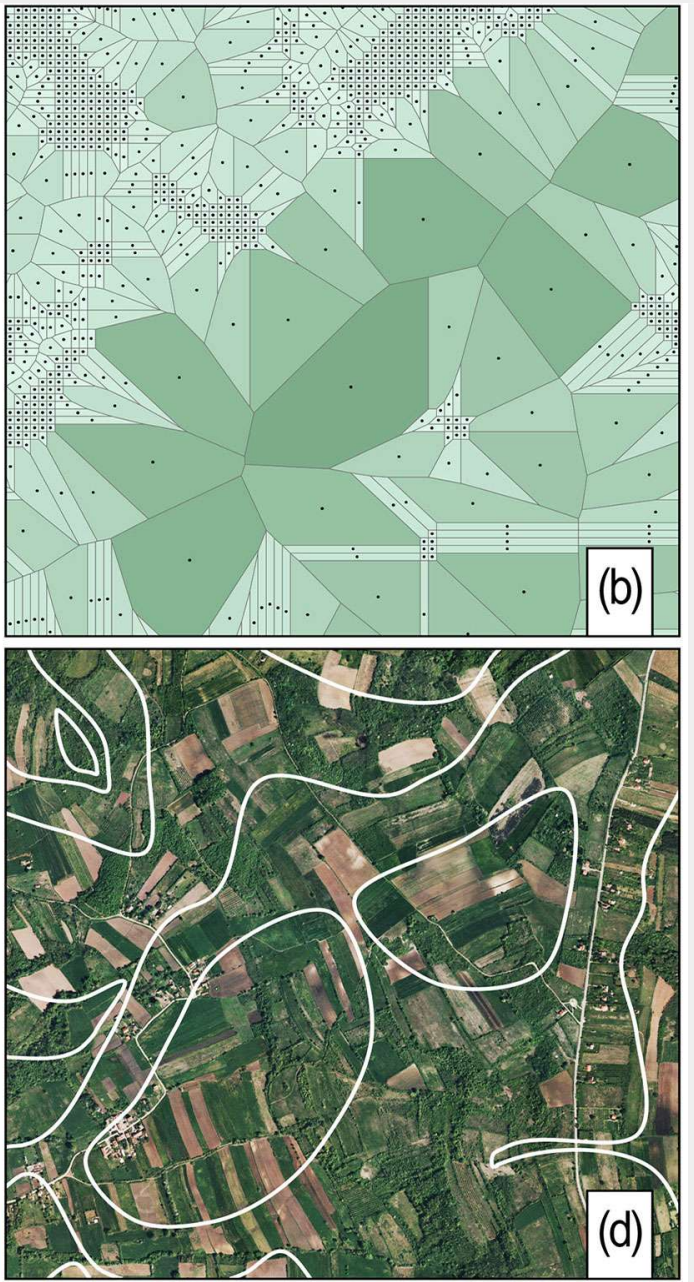

Fig. 3 - Procedures for generating an interpolated grid. Illustration of the applied technique for defining the level of connectivity between NSN elements. (a) Point data grid with 20 m resolutions which represents the spatial coverage of NSN elements; (b) generated Thiessen polygons and their centroids with added numerical attributes; (c) interpolated data that represents levels of connectivity; and (d) their locations in the actual section of the investigated area. 
Fig. 4 - Distribution of the levels of connectivity in landscape structure in 2011 (a) and landscape structure based on the Urban Forest Management Plan (b).
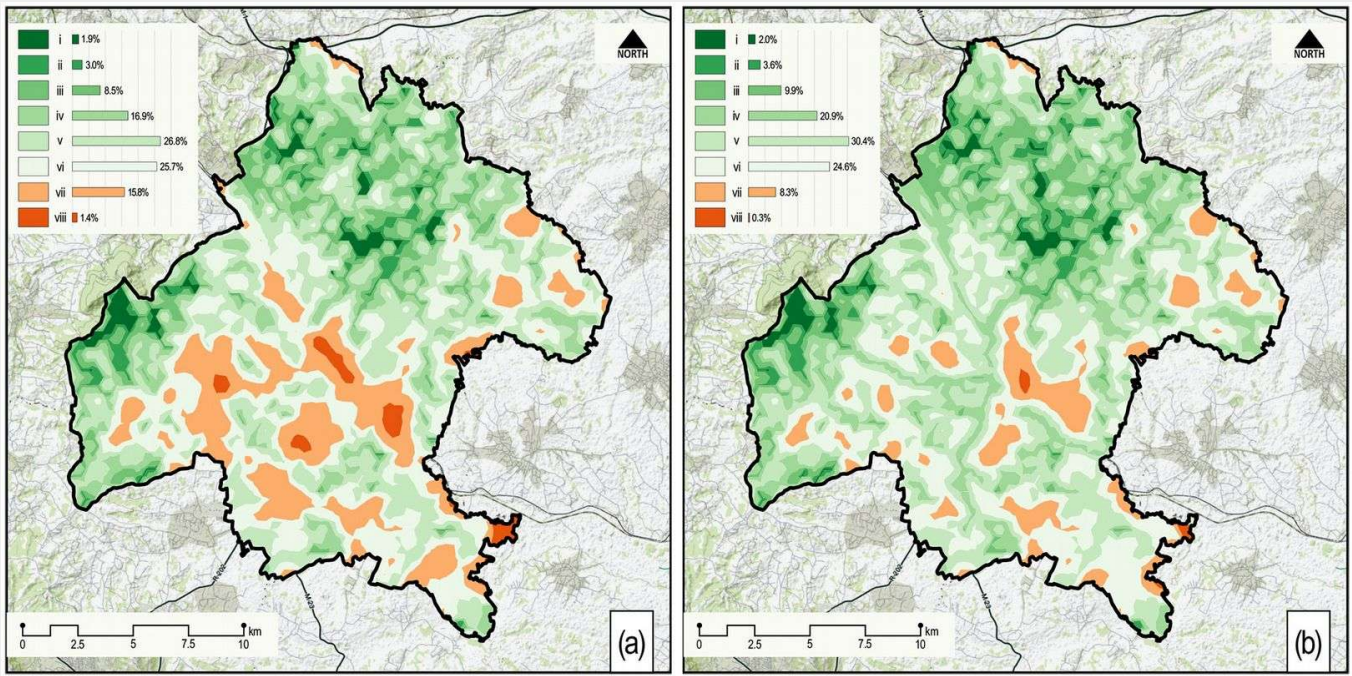

The construction of Thiessen polygons (Fig. 3b) is an appropriate method for determining the zones of spatial influence of NSN elements. This method divides the investigated area into zones that are equidistant from the NSN elements and at the same time the surfaces of the generated polygons indicate the lack of relevant patches (Geneletti 2002). The areas of the polygons were treated as non-dimensional values and were added to their centroids, which are suitable for the creation of a continuous grid using interpolation techniques. An interpolated grid provides materialisation of the concept of gradients, which integrates the spatial and functional aspects of NSN elements (Colantonio Venturelli \& Gall 2006). Given that there is no research that offers precise guidelines for the selection of an adequate model of geostatistical interpolation, an empirical Bayesian kriging was applied (Fig. 3C, Fig. 3d). This method began to emerge relatively recently in applied geostatistics and the prediction of various environmental issues. The main advantage of this model is that, with the use of multiple semivariograms, it can automatically generate a valid kriging model unlike other types of kriging that require manual adjustment (Samsonova et al. 2017).

\section{Results and discussion}

According to the defined methodological procedures, the landscape structure was analysed at two stages: $(A)$ the condition of the structure from 2011, and (B) the condition of the structure developed in the Urban Forest Management Plan for the City of Belgrade - Mladenovac Municipality (Medarević et al. 2013). The result was a continuous grid with data values categorised into different connectivity levels of NSN elements for the conditions A and B (Fig. 4). Continuous data values (grids) were classified using geometrical intervals which gives an appropriate balance between middle and extreme values and also gives comprehensive results which are represented in the form of numeric values and maps. The basic information from this kind of grid identifies the zones which lack NSN elements, and/or levels of connectivity. The values in the grid are numerical and represent the surface (in metres) on which the influence of NSN elements is present in terms of size and number.

The results obtained illustrate the spatial distribution of different connectivity levels between NSN elements, in relation to two conditions of the landscape structure. A higher level of connectivity is represented by lower values in the grid, which point to a zone with a higher number of NSN elements in terms of surface and number.

Lower levels of connectivity refer to higher values in the grid and point to a lack of NSN elements in the landscape structure. The rate of change in surfaces of various levels of connectivity fits the asymmetric quadratic function, i.e., the change moves towards positive values in lower levels (i: +6.7\%; ii: $+18.9 \%$; iii: +16.5 ), reaches a

maximum of positive change at the iv $(+23.4 \%)$ level and then declines with lower connectivity (v: $-13.8 \%$; vi: $-4.1 \%$; vii: $-47.7 \%$; viii: -81.1\%).

It was a challenge to identify categories which reflect a multifunctional value in the achieved level of connectivity of NSN elements. The categories indicate the level of ecosystem services required for its achievement, which include both the biodiversity and outdoor recreation potential. A research approach oriented towards representing multifunctional values of a green infrastructure has determined the categorisation of level $v i$ as a zone with established connectivity, although it appeared to show similar statistical reactions to the connectivity of levels vii and viii, i.e., a reduction in surface (by $4.1 \%$ ) and a reduction of total surface of NSN elements (30.1\%). However, both time intervals show a certain number of NSN elements (A: 81; B: 78) with an appropriate walking distance position (less

\begin{tabular}{|c|c|c|c|c|c|c|}
\hline 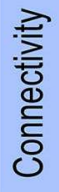 & ब & 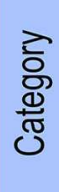 & $\begin{array}{l}\text { Achievement of } \\
\text { connectivity }\end{array}$ & $\begin{array}{l}\text { Change of } \\
\text { number of } \\
\text { NSN } \\
\text { elements } \\
{[\%]}\end{array}$ & $\begin{array}{l}\text { Change of } \\
\text { total sum } \\
\text { of NSN } \\
\text { elements } \\
{[\%]}\end{array}$ & $\begin{array}{l}\text { Distance } \\
\text { from NSN } \\
\text { elements } \\
{[\mathrm{m}]}\end{array}$ \\
\hline \multirow{6}{*}{$\stackrel{\mathscr{0}}{\longleftarrow}$} & i & \multirow{3}{*}{1} & \multirow{3}{*}{ High } & \multirow{3}{*}{12} & \multirow{3}{*}{13} & \multirow{3}{*}{100} \\
\hline & ii & & & & & \\
\hline & iii & & & & & \\
\hline & iv & \multirow[t]{2}{*}{ II } & \multirow[t]{2}{*}{ Moderate } & \multirow[t]{2}{*}{14} & \multirow[t]{2}{*}{5} & \multirow[t]{2}{*}{$100-500$} \\
\hline & v & & & & & \\
\hline & vi & III & Low & -2 & -30 & $500-1000$ \\
\hline \multirow[t]{2}{*}{ 은 } & vii & \multirow[t]{2}{*}{ IV } & \multirow[t]{2}{*}{ I } & \multirow[t]{2}{*}{ I } & \multirow[t]{2}{*}{ I } & \multirow[t]{2}{*}{ I } \\
\hline & viii & & & & & \\
\hline
\end{tabular}

Fig. 5 - Categories and achievement of connectivity. The level of connectivity is represented in the landscape metric parameters (the number, surface and distance of NSN elements) and nominal and ordinal scale. 


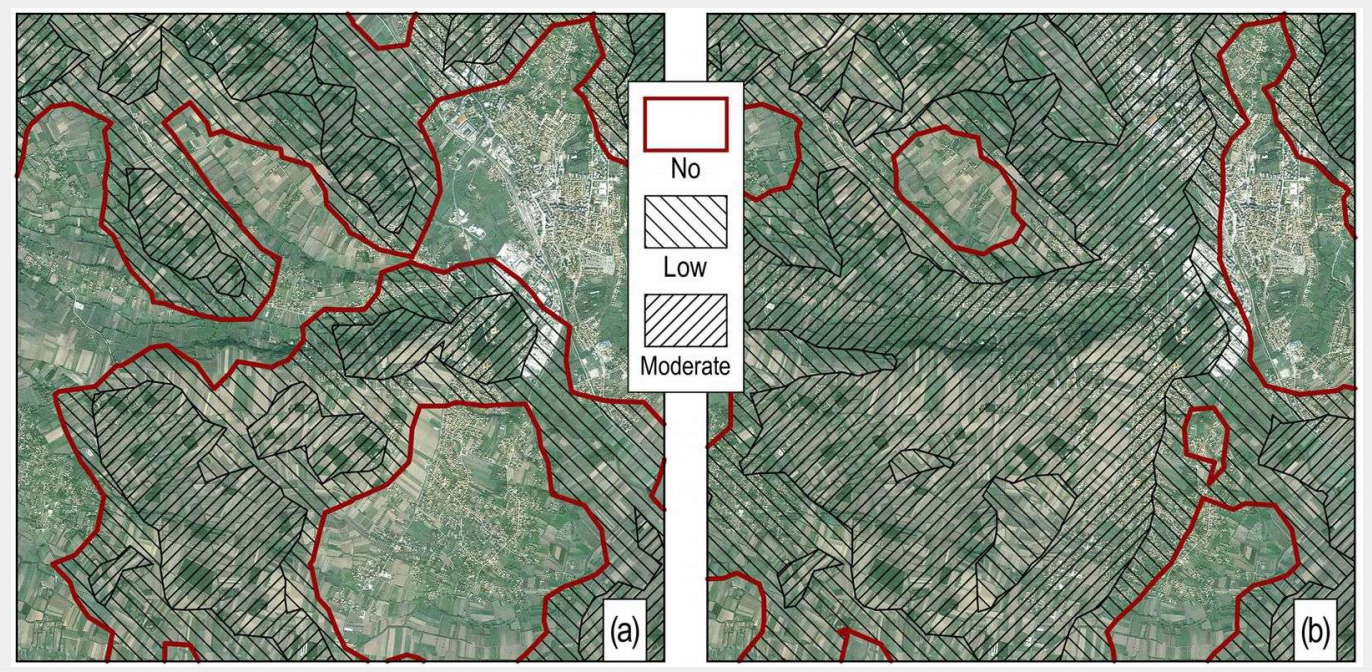

Fig. 6 - Zones of priorities for improving connectivity with Gl. The zones with medium and low connectivity have increased in relation to the zones with no connectivity between NSN elements. In contrast to the state in (a), state (b) shows how the Urban Forest Management Plan has reduced the mutual distance and isolation of the better categories of connectivity. The zones with no connectivity are located in urban and agricultural lands use areas.

than $1 \mathrm{~km}$ ), which places this level of connectivity in the group of categories which possess a multifunctional level.

A total of three spatial categories were created referring to landscape structures with different levels of connectivity, and one with no connectivity of NSN elements (Fig. 5).

The categories with established connec tivity of NSN elements cover $280.15 \mathrm{~km}^{2}$ of the surface at time interval $A$, while the categories with no established connectivity cover $58.49 \mathrm{~km}^{2}$. In the Urban Forest Management Plan (time interval B) the categories with established connectivity of NSN elements cover $309.67 \mathrm{~km}^{2}$ (an increase in surface area of $10.54 \%$ ) while the categories with no established connectivity cover $28.97 \mathrm{~km}^{2}$ (a reduction in surface area of $50.47 \%$ ). The spatial category of high connectivity (I category) represents a core area of the influence of the NSN elements. Within this category the landscape metric parameters that emphasise the multifunctionality value of a green infrastructure have increased - the total sum of NSN elements increased by $13 \%$ and the number of NSN elements was raised by $12 \%$. The zones with moderate connectivity (II category) show a greater change in the number of NSN elements (14\%) but a less significant change of the total sum of NSN elements (5\%). These changes in categories of connectivity justify the classification of connectivity because a less extensive change in the sum of NSN elements, in the moderate as opposed to the high category, points to zones in which NSN elements are less distant from each other in space.

Scientific literature frequently mentions the lack of quantitative data bases which would support the effective application of ecosystem services in planning practice. Nonetheless, in their review Albert et al. (2014b) found that semi-quantitative comparative approaches based on ordinal scales have often proved to be sufficient. In the Urban Forest Management Plan the application of ecosystem services is represented on an ordinal, and/or nominal scale.
According to the indicators of degree of connectivity, represented in the landscape metric parameters (the number, surface and distance of NSN elements), nominal and/or ordinal values are defined (low, moderate and high connectivity). The multifunctional values of the achieved ecosystem services such as supporting ecosystem services and cultural ecosystem services presented in this way, "derive priorities for improving $\mathrm{Gl}$ elements as well as the links and gaps between them" (Davies et al. 2006). In the parts of the research area which showed a high degree of connectivity (category I), measures must be taken to preserve the structure of the NSN elements (Fig. 6). In the areas which showed moderate and low connectivity (categories II and III), planned measures should be applied to introduce new NSN elements and establish connections between existing elements. The areas in the structure of the landscape which showed the lowest values were those dominated by heterogeneous landscape elements (those sections of the landscape dominated by urban and agricultural heterogeneous landscape elements). Thus, the multifunctional values of ecosystem services achieved allow the definition of new goals and approaches for the realisation of $\mathrm{Gl}$ concepts in the context of sector planning in urban and agricultural planning.

The Gl concept in the Urban Forest Management Plan involves the application of a landscape approach to research, and connectivity is established as a new goal of afforestation. In this way the achieved results are not presented in the traditional manner alone, as the degree of afforestation, but rather through the level of connectivity achieved. With the afforestation of a new 229 ha of non-forested land, the level of afforestation is increased by $1.1 \%$, reaching $13.6 \%$ of the entire area, which is above the average for the Belgrade metropolitan area (11.2\%), but still well below the level of afforestation in the Republic of Serbia as a whole, which is $30.6 \%$. At the same time, the areas with a greater degree of connectivity are increased by $8.72 \%$, which represents a valuable result, not just from the point of view of the achieved services to biodiversity supporting ecosystem services but from the point of view of the stability of the landscape as a whole (Antrop \& Van Eetvelde 2000, Ahern 2013).

\section{Conclusions}

A growing number of researchers view the planning of the spatial development of urban landscapes in a contemporary context as a challenge without precedent. The existing research methods are being reviewed, along with the goals of sustainable urban development. The majority of authors advocate interdisciplinary discourse when planning at the landscape scale, which presupposes a landscape ecological approach aimed at the creation of sustainable and resilient urban landscapes. This means that, among other things, it is essential to increase the level of biodiversity and connectivity through the establishment of an ecological network by linking existing natural and semi-natural elements, paying attention to the multi-functional values of the ecosystem.

Although there are problems regarding the implementation of the concept of green infrastructure and no adequate methods exist for measuring the achieved results, in conditions of climate change the green infrastructure concept turns out to be the most suitable for flexible planning in urban landscapes. The spatial dimension of the $\mathrm{Gl}$ concept, which establishes a physical connection between NSN elements, defines the landscape pattern and helps shape a resilient urban landscape. At the same time, the functional dimension ensures the concept is viewed through various ecosystem services.

Connectivity is a multifunctional value of the green infrastructure concept, and it is achieved via spatial distribution and the connection of NSN elements in Gl. It is measurable in terms of aspects of the various ecosystems. At the same time, the level of recognised connectivity repre- 
sented as a multifunctional value which integrates cultural and supporting ecosystem services (recreation and biodiversity) and establishes a degree of stability in urban landscapes.

Urban forestry is playing a more and more important role in the collaborative planning of urban landscapes, most significantly in the implementation of the green infrastructure concept. In Serbia, a multiscale spatial dimension and the multifunctional dimension of the green infrastructure have been applied at national and regional levels of spatial development planning. The realisation of the green infrastructure concept is presented through the example of the Urban Forest Management Plan for the City of Belgrade - Mladenovac Municipality. The results of using the spatial-ecological approach in creating the plan and establishing connectivity as a new aim in forest management planning show that the implementation of the green infrastructure concept, and the achieved multifunctional ecosystem values, can be presented on the basis of the parameters of landscape metrics. This approach requires further practical research, which would actualise the paradigm of planning at the landscape scale, in which the green infrastructure concept is used as the basis for understanding and co-operation of different participants in the process of planning the spatial development of urban landscapes.

\section{References}

Ahern J (2011). From fail-safe to safe-to-fail: sustainability and resilience in the new urban world. Landscape and Urban Planning 100 (4): 341-343. - doi: 10.1016/j.landurbplan.2011.02.021 Ahern J (2013). Urban landscape sustainability and resilience: the promise and challenges of integrating ecology with urban planning and design. Landscape Ecology 28 (6): 1203-1212. doi: 10.1007/s10980-012-9799-z

Ahern J (2016). Novel urban ecosystems: concepts, definitions and a strategy to support urban sustainability and resilience. Landscape Architecture Frontiers 4 (1): 10-21. [online] URL: http://go.galegroup.com/ps/anonymous?id=GA LE|A459715410

Albert C, Aronson J, Furst C, Opdam P (2014a). Integrating ecosystem services in landscape planning: requirements, approaches, and impacts. Landscape Ecology 29 (8): 1277-1285. . doi: 10.1007/s10980-014-0085-0

Albert C, Hauck J, Buhr N, Von Haaren C (2014b). What ecosystem services information do users want? Investigating interests and requirements among landscape and regional planners in Germany. Landscape Ecology 29 (8): 1301-1313. doi: $10.1007 /$ s10980-014-9990-5

Antrop M, Van Eetvelde V (2000). Holistic aspects of suburban landscapes: visual image interpretation and landscape metrics. Landscape and Urban Planning 50: 43-58. - doi: 10.1016/S0169-2046(00)00079-7

Benedict M, McMahon E (2006). Green infrastructure - Linking landscapes and communities. Island Press, Washington, DC, USA, pp.
320.

Billeter R, Liira J, Bailey D, Bugter R, Arens P, Augenstein I, Aviron S, Baudry J, Bukacek R, Burel F (2008). Indicators for biodiversity in agricultural landscapes: a pan-European study. Journal of Applied Ecology 45: 141-150. - doi: 10.1111/j.1365-2664.2007.01393.x

Botequilha Leitao A, Ahern J (2002). Applying landscape ecological concepts and metrics in sustainable landscape planning. Landscape and Urban Planning 59 (2): 65-93. - doi: 10.1016/So1 69-2046(02)00005-1

Botequilha Leitao A, Miller J, Ahern J, McGarigal K (2006). Measuring landscapes. A planner's handbook. Island Press, Washington DC, USA, pp. 272.

Casado-Arzuaga I, Onaindia M, Madariaga I, Verburg PH (2014). Mapping recreation and aesthetic value of ecosystems in the Bilbao Metropolitan Greenbelt (northern Spain) to support landscape planning. Landscape Ecology 29: 1393-1405. - doi: 10.1007/s10980-013-9945-2

Chan KMA, Shaw MR, Cameron DR, Underwood EC, Daily GC (2006). Conservation planning for ecosystem services. PLOS Biology 4 (11): 21382152. - doi: 10.1371/journal.pbio.0040379

Colantonio Venturelli R, Gall A (2006). Integrated indicators in environmental planning: Methodological considerations and applications. Ecological Indicators 6: 228-237. - doi: 10.1016/j.eco lind.2005.08.023

Correa Ayram CA, Mendoza ME, Etter A, Perez Salicrup DR (2016). Habitat connectivity in biodiversity conservation: a review of recent studies and applications. Progress in Physical Geography 40 (1): 7-37. - doi: 10.1177/03091333155987 13

Daniel TC (2001). Whither scenic beauty? Visual landscape quality assessment in the 21st century. Landscape and Urban Planning 54: 267281. - doi: 10.1016/S0169-2046(01)00141-4

Daniel TC, Muhar A, Arnberger A, Aznar O, Boyd JW, Chan KMA, Costanza R, Elmqvist T, Flint CG, Gobster PH, Gret-Regamey A, Lave R, Muhar S, Penker M, Ribe RG, Schauppenlehner T, Sikor T, Soloviy I, Spierenburg M, Taczanowska K, Tam J, Von Der Dunk A (2012). Contributions of cultural services to the ecosystem services agenda. Proceedings of the National Academy of Sciences USA 109 (23): 8812-8819. - doi: 10.1073/pnas.1114773109

Davies C, MacFarlane R, McGloin C, Roe M (2006). Green infrastructure planning guide. North East Community Forest, Anfield Plain, UK, pp. 1-45. - doi: 10.13140/RG.2.1.1191.3688

De Groot RS, Alkemade R, Braat L, Hein L, Willemen $L$ (2010). Challenges in integrating the concept of ecosystem services and values in landscape planning, management and decision making. Ecological Complexity 7 (3): 260-272. doi: 10.1016/j.ecocom.2009.10.006

Dolnicar S, Crouch Gl, Long P (2008). Environment friendly tourists: what do we really know about them? Journal of Sustainable Tourism 16 (2): 197-210. - doi: 10.2167/jost738.0

EC (2013). Green Infrastructure (GI) - Enhancing Europe's natural capital. Communication from the Commission to the European Parliament, the Council, the European Economic and Social Committee and the Committee of the Regions, European Commission, 6 May 2013, Brussels,
Belgium, pp. 11.

Fahrig $L$ (2003). Effects of habitat fragmentation on biodiversity. Annual Review of Ecology, Evolution and Systematics 34: 487-515. - doi: 10.1146/annurev.ecolsys.34.011802.132419

Forman RTT (1995). Land mosaics: the ecology of landscapes and regions. Cambridge University Press, USA, pp. 656.

Geneletti D (2002). Ecological evaluation for environmental impact assessment. Netherlands Geographical Studies, NGS, Utrecht, Netherlands, pp. 218. [online] URL: http:// webapps.itc.utwente.nl/librarywww/papers/ph d_2002/geneletti.pdf

Hansen R, Pauleit S (2014). From multifunctionality to multiple ecosystem services? A conceptual framework for multifunctionality in green infrastructure planning for urban areas. AMBIO 43 (4): 516-529. - doi: 10.1007/s13280-014-0510-2 Hauck J, Schweppe-Kraft B, Albert C, Gorg C, Jax K, Jensen R, Furst C, Maes J, Ring I, Honigova I, Burkhard B, Mehring M, Tiefenbach M, Grunewald K, Schwarzer M, Meurer J, Sommerhauser M, Priess JA, Schmidt J, Gret-Regamey A (2013). The promise of the ecosystem services concept for planning and decision making. GAIA - Ecological Perspectives for Science and Society 22 (4): 232-236. - doi: 10.14512/gaia.22. 4.6

Hornsten L, Fredman P (2000). On the distance to recreational forests in Sweden. Landscape and Urban Planning 51: 1-10. - doi: 10.1016/S0169-2046(00)00097-9

Kumar S, Stohlgren TJ, Chong GW (2006). Spatial heterogeneity influences native and non-native plant species richness. Ecology 87 (12): 31863199. - doi: 10.1890/0012-9658(2006)87[3186:SH INAN]2.0.CO;2

Lafortezza R, Davies C, Sanesi G, Konijnendijk CCC (2013a). Green infrastructure as a tool to support spatial planning in European urban regions. iForest 6: 102-108. - doi: 10.3832/iforo7 23-006

Lafortezza R, Sanesi G, Chen J (2013b). Largescale effects of forest management in Mediterranean landscapes of Europe. iForest 6: 342346. - doi: 10.3832/iforog60-006

Lee SW, Ellis CD, Kweon BS, Hong SK (2008). Relationship between landscape structure and neighbourhood satisfaction in urbanized areas. Landscape and Urban Planning 85: 60-70. - doi: 10.1016/j.landurbplan.2007.09.013

McGarigal K, Marks BJ (1995). FRAGSTATS: Spatial pattern analysis program for quantifying landscape structure. Forest Science Department, Oregon State University, Corvallis, USA, pp. 141. - doi: 10.2737/PNW-GTR-351

Medarević M, Banković S, Karadžić D, Mihajlović Lj, Pantić D, Šljukić B, Petrović N, Obradović S, Vasiljević N, Pešić B, Filipović D (2013). Urban forest management plan for the city of Belgrade - Mladenovac Municipality. Faculty of Forestry, University of Belgrade, Secretariat for Environmental Protection, Belgrade, Serbia, pp. 92. [in Serbian]

Mell IC (2009). Can green infrastructure promote urban sustainability? Engineering Sustainability 162 (1): 23-34. - doi: 10.1680/ensu.2009. 162.1.23

Millennium Ecosystem Assessment (2005). Ecosystems and human well-being: synthesis. 
Island Press, Washington DC, USA, pp. 155.

Nassauer JI, Opdam P (2008). Design in science: extending the landscape ecology paradigm. Landscape Ecology 23: 633-644. - doi: 10.1007/ s10980-008-9226-7

Ndubisi F (2002). Ecological planning: a historical and comparative synthesis. Johns Hopkins Press, Baltimore and London, pp. 304.

Noss RE (1990). Indicators for monitoring biodiversity: a hierarchical approach. Conservation Biology 4 (4): 355-364. - doi: 10.1111/j.1523-1739. 1990.tboo309.x

Pauleit S, Liu L, Ahern J, Kazmierczak A (2011). Multifunctional green infrastructure planning to promote ecological services in the city. In: "Urban Ecology Patterns, Processes, and Applications" (Niemela J, Breuste G, Elmqvist T, Guntenspergen $\mathrm{G}$ James $\mathrm{P}$, McIntyre T eds). Oxford University Press, New York, USA, pp. 272-285.

Poelmans L, Van Rompaey A (2009). Detecting and modelling spatial patterns of urban sprawl in highly fragmented areas: a case study in the Flanders-Brussels region. Landscape and Urban Planning 93: 10-19. - doi: 10.1016/j.landurbplan. 2009.05.018

Prokop G, Jobstmann H, Schonbauer A (2011). Report on best practices for limiting soil sealing and mitigating its effects in EU-27. Technical Report 2011-50, Environment Agency, European
Communities, Austria, pp. 231.

Prugh LR, Hodges KE, Sinclair ARE, Brashares JS (2008). Effect of habitat area and isolation on fragmented animal populations. Proceedings of the National Academy of Sciences USA 105: 20770-20775. - doi: 10.1073/pnas.0806080105 Randrup TB, Konijnendijk C, Dobbertin MK, Pruller R (2005). The concept of Urban Forestry in Europe. In: "Urban Forests and Trees: A Reference Book” (Konijnendijk CC, Nilsson K, Randrup T, Schipperijn J eds). Springer, Berlin Heidelberg, Germany, pp. 9-21. - doi: 10.1007/3-54027684-X_2

Rudnick DA, Ryan SJ, Beier P, Cushman SA, Dieffenbach F, Epps CW, Gerber LR, Hartter J, Jenness JS, Kintsch J, Merenlender AM, Perkl RM, Preziosi DV, Trombulak SC (2012). The role of landscape connectivity in planning and implementing conservation and restoration priorities. Issues in Ecology 16: 1-20. [online] URL: http://scholars.unh.edu/geog_facpub/19/

Samsonova VP, Blagoveshchenskii N, Meshalkina YL (2017). Use of empirical Bayesian kriging for revealing heterogeneities in the distribution of organic carbon on agricultural lands. Soil Chemistry 50 (3): 305-311. - doi: 10.1134/S1064 229317030103

Sax DF, Gaines SD (2003). Species diversity: from global decreases to local increases. Trends in
Ecology and Evolution 18 (11): 561-566. - doi: 10.1016/S0169-5347(03)00224-6

Tobias S (2013). Preserving ecosystem services in urban regions: challenges for planning and best practice examples from Switzerland. Integrated Environmental Assessment and Management 9 (2): 243-251. - doi: 10.1002/ieam.1392 Vasiljević N, Radić B, Šljukić B, Ristić R (2016). Landscape planning and green infrastructure in Serbia: from national to Belgrade city planning. In: Proceedings of " 5 th $F a b o s$ Conference on Landscape and Greenway Planning - Landscapes and Greenways of Resilience" (Valanszki I, Jombach S, Filep-Kovacs K, Fabos JG, Ryan RL, Lindhult MS, Kollanyi L eds). Szent István University, Budapest (Hungary) 01 July 2016. University of Massachusetts, Amherst, MS, USA, pp. 389-397.

Weyland F, Laterra P (2014). Recreation potential assessment at large spatial scales: a method based in the ecosystem services approach and landscape metrics. Ecological Indicators 39: 34-43. - doi: 10.1016/j.ecolind.2013.11.023 Zonneveld IS (1995). Land ecology: an introduction to landscape ecology as a base for land evaluation, land management and conservation. SPB Academic Publishing, Amsterdam, Netherlands, pp. 199. 